\title{
TELEPÜLÉSI TÉNYEZŐK FONTOSSÁG-ELÉGEDETTSÉG ELEMZÉSE A BALATON TÉRSÉGBEN
}

\author{
IMPORTANCE AND SATISFACTION ANALYSIS OF MUNICIPAL \\ FACTORS IN THE BALATON AREA
}

\begin{abstract}
A kutatás tárgya a Balaton kiemelt turisztikai fejlesztési térség településeihez kötődő lakosság véleményének vizsgálata a települési tényezőkkel kapcsolatban. A vizsgált adatok 2018 és 2019-ben végzett primer kérdőíves felmérésből származnak, melynek során 27 települési tényezőt vizsgáltak meg a szerzők, az értékelhető minta elemszáma 1201 fő. A tanulmány az ISA (Importance - Satisfaction Analysis) fontosság-elégedettség módszert alkalmazza a Balaton térség települési tényezőinek értékelése során, ugyanakkor elemzik a mátrixtechnikák módszertani dilemmáit is. A kutatás célja annak a kérdésnek a megválaszolása, hogy milyen települési fejlesztésekre vágynak leginkább a balatoniak. E kérdés megválaszolásához az egyes települési tényezők általuk érzékelt fontosságát és az ezekkel való elégedettségüket használták fel a szerzők. A tanulmányban alkalmazott módszertan mind a gyakorlati, mind a tudományos szakemberek számára használható keretrendszert alkalmaz. Az elemzések eredményei útmutatást nyújthatnak a döntéshozóknak a beavatkozás fő területeinek meghatározásában.
\end{abstract}

\section{Kulcsszavak: fontosság-elégedettség elemzés, Balaton térség, települési tényezők, életkor, kérdőíves felmérés}

This paper investigated the opinion of local residents about 27 municipal factors, with a geographical focus on the Balaton highlighted tourism development region. Data from a primary survey were used for the analyses, based on a questionnaire conducted in 2018-2019, which yielded a total evaluable sample of 1,201 people. The importance-satisfaction analysis (ISA) method was employed to evaluate the settlement factors of the Balaton region, while the methodological dilemmas of the matrix techniques were also examined. This research sought to determine what kind of settlement developments the people of Balaton want the most. To answer this, the perceived importance of each settlement factor and the satisfaction each settlement factor elicited were considered in the analysis. The methodology applied in this study can provide a useful framework for both practical and scientific experts, and the results of the analyses can provide guidance to decision makers in identifying key areas for intervention.

Keywords: Importance-Satisfaction Analysis (ISA), Balaton area, municipal factors, age, questionnaire

\section{Finanszírozás/Funding:}

A szerzők a tanulmány elkészítésével összefüggésben nem részesültek pályázati vagy intézményi támogatásban.

The authors did not receive any grant or institutional support in relation with the preparation of the study.

\section{Szerzők/Authors:}

Dr. Banász Zsuzsanna, egyetemi docens, Pannon Egyetem, (banasz.zsuzsanna@gtk.uni-pannon.hu)

Dr. Fekete-Berzsenyi Hajnalka, egyetemi adjunktus, Pannon Egyetem, (fekete-berzsenyi.hajnalka@gtk.uni-pannon.hu)

A cikk beérkezett: 2020. 09. 01-én, javítva: 2020. 10. 23-án, elfogadva: 2021. 03. 10-én.

This article was received: 01. 09. 2020, revised: 23. 10. 2020, accepted: 10. 03. 2021.

$\mathrm{A}$ Balaton (Közép-Európa legnagyobb tava) hazánk turizmusában játszott szerepe vitathatatlan, Budapest után a második leglátogatottabb térség (KSH, 2020). Az 1. ábra szemlélteti, hogy hogyan alakult 2019-ben a balatoni, illetve a budapesti turisztikai régióban a külföldi, belföldi, illetve az összesített vendégéjszakák száma.
Az 1. ábra kiemelten kezeli a nyári főszezon hónapjainak (július és augusztus) összesített adatait. Az ábra alapján megállapítható, hogy egész évben és nyáron is a külföldiek inkább Budapestet preferálják a Balatonhoz képest (1. ábra A része). A belföldiekre ennek ellenkezője igaz: akár a teljes év, akár csak a nyári főszezon képezi a meg- 
figyelés tárgyát, a magyarok inkább a Balatont keresik fel, mint Budapestet (1. ábra B része). Eltekintve a vendégéjszakát foglalók állampolgárságától, 2019-ben Budapesten foglaltak több vendégéjszakákát, azonban a nyári hónapokban a Balatonon (1. ábra $\mathrm{C}$ része). A jövőben érdekes lesz megfigyelni, hogy 2020-ban hogyan módosul az 1. ábra a COVID-19 koronavírus járvány miatt 2020 márciusától bevezetett szigorító intézkedések következtében.

\section{A kereskedelmi szálláshelyeken eltöltött (külföldi, belföldi, összesített) vendégéjszakák száma turisztikai régiónként (Budapest, Balaton, összesen), 2019 (ezer éjszaka)}

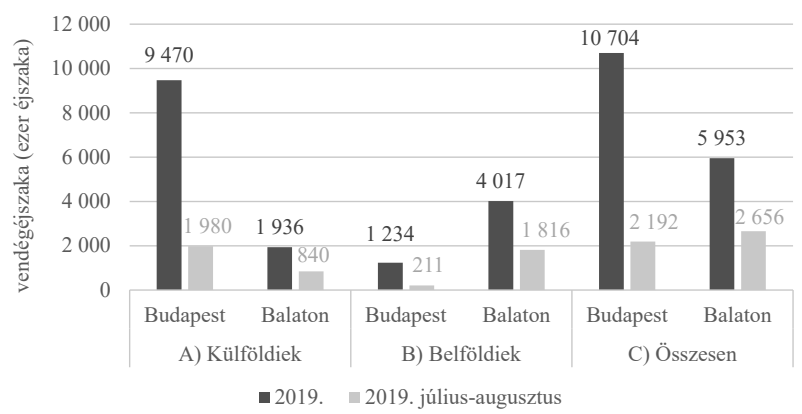

Forrás: saját szerkesztés (KSH, 2020) adatai alapján

A Balaton melletti települések vezetőinek nemcsak a nyáron koncentrálódó turisták fontosak, hanem a helyi lakosság megtartása is. Ha a helyi lakosok nem elégedettek a települési tényezőkkel, akkor ez arra ösztönözheti őket, hogy elköltözzenek a településről, vagy akár a térségből is (Piskóti, Nagy, Molnár, \& Marien, 2012; Tóth-Kaszás, 2018). Viszont a lakosoknak a településükről alkotott pozitív véleménye kihatással lehet a területre érkező turisták számára is. Ezek miatt fontos a helyiek véleményének feltárása, amelyet mi is tettünk e kutatásunkban.

A kutatás tárgyát a Balaton kiemelt turisztikai fejlesztési térség (GOV, 2016) - a továbbiakban röviden Balaton térség - népessége képezi. E térségbe tartozó 174 település többsége (170) a Balaton kiemelt üdülőkörzet (GOV, 2000) 179 településének is a része, közülük 42 település a Balaton partja mentén található. A legfontosabb különbség (a Balaton kiemelt turisztikai fejlesztési térség és a Balaton kiemelt üdülőkörzet között), hogy az általunk vizsgált térségbe egy megyeszékhely (Veszprém) is beletartozik, míg az üdülőkörzetbe nem.

Mivel a Balaton térség kiterjedését kormányrendelet határozza meg (GOV, 2016), a klasszikus térszervező jellemzők (egységes térszerkezeti egység, természeti jellemzők, társadalmi-gazdasági jellemzők, kulturális identitás, területi igazgatás funkciói (Nemes Nagy, 1998, 2016)) közül csak néhány érvényesül. A térség táji és természeti homogenitása inkább csak a part menti településekre jellemző, ugyanígy a társadalmi-gazdasági jellemzők hasonlósága is, föképp az ott tapasztalható turizmus miatt. A Balaton térség nem egy közigazgatási egység, inkább ,közös területfejlesztési, idegenforgalmi, gazdaságfejlesztési, környezetvédelmi gondok megoldásának színtere” (Oláh, 2013).
A tanulmány célja annak a kutatási kérdésnek a megválaszolása, hogy milyen települési fejlesztésekre vágynak leginkább a balatoniak? E kérdést nem lehet megválaszolni adatbázisokban hozzáférhető, úgynevezett „kemény” indikátorok alapján. A lakosság véleménye a „puha” indikátorok körébe tartozik, amelyek mérése csak az érintettek megkérdezése által lehetséges (Koltai, 2005).

A lakosság véleményének feltárásának érdekében primer kérdöíves felmérést végeztünk, amelynek keretében megkérdeztük a lakosok véleményét több települési tényezőről: mennyire tartják fontosnak, illetve mennyire elégedettek ezekkel. A vágyott fejlesztések proxyjaként az elégedettség és a fontosság közti rést használjuk, amely gyakori elnevezése az angol „gap”. Ezáltal ajánlások tehetők a döntéshozók számra arról, hogy mely települési tényezőket lenne érdemes fejleszteni a lakosság nagyobb elégedettsége érdekében? A tanulmány egy olyan prioritást feltáró módszertant mutat be, ami a Balaton térség lakossága által az egyes települési tényezőkkel kapcsolatban érzékelt fontosságon és elégedettségen alapul.

Feltételeztük, hogy a vélemények eltérnek a fiatalabb, illetve idősebb korosztályban, ezért az eredményeket e két korcsoportra bontva mutatjuk be. Így finomíthatók a döntéshozóknak nyújtott fejlesztési ajánlások, attól függően, hogy az önkormányzat a fiatalabb vagy az idősebb lakosság preferenciáit helyezi elötérbe. A kutatás jelentőségét az adja, hogy legjobb tudomásunk szerint eddig még nem készültek ilyen ajánlások a Balaton térségre vonatkozóan.

A tanulmány a továbbiakban a következő felépítést követi. A kérdés megválaszolásához először áttekintjük a fontosság és elégedettség méréséhez kapcsolódó szakirodalmat, valamint az ennek kapcsán felmerülő módszertani vitákat. Ezt követően bemutatjuk az elemzéshez felhasznált keretet: a felhasznált adatokat és az alkalmazott módszertant, majd az eredmények ismertetésére térünk át. Végül - megemlítve kutatásunk korlátait, és annak lehetséges jövőbeli irányait - összegezzük. Az eredmények összegzése, és az ezekből levonható gyakorlati következtetések megfogalmazása után kitérünk a kutatásunk korlátaira, valamint annak lehetséges jövőbeli irányaira.

\section{Elméleti háttér}

A szakirodalmi áttekintés keretében először azt mutatjuk be, hogy a lakossági felmérésekben tipikusan milyen települési tényezők képezik a megfigyelés tárgyát, majd áttérünk a réselemzés (fontosság-elégedettség) eredményeinek prezentálására irányuló módszertani vitákra.

\section{Települési tényezők}

A lakossági felmérésekben a települési tényezőknek tipikusan a következő kategóriái szerepelnek: települési adottságok (például infrastruktúra, megközelíthetőség, természeti környezet), demográfiai és gazdasági jellemzők (például lakosság korösszetétele, munkalehetőségek, foglalkoztatás), szolgáltatások (például egészségügy, oktatás, közbiztonság, infrastruktúra, közterületek rendezettsége) (Koltai, 2005, 2015, 2016; Marien, 2012; Piskóti et al., 2012; Piskóti, Dankó, Molnár, Nagy, \& Szántó, 2013; 
Insch \& Florek, 2010; Zenker, Petersen \& Aholt, 2013; Nigro \& Císaro, 2016). Szirmai és Váradi (2009) szerint a lakosság általános - településsel kapcsolatos - közérzetéhez a gazdasági jellemzőknél fontosabbak a társadalmiak, úgymint a közbiztonság, vagy az életkörülmények javulása. Mindezek mellett fontos, hogy a kérdéseket igazítsuk a régió speciális karakterisztikájához is (Lengyel, 2003).

A lakosságnak a települési tényezőkről való véleményét felmérő kutatásoknak három fajtája van attól függően, hogy csak azok fontosságára kérdeznek rá (Koltai, 2005, 2015, 2016; Marien, 2012; Piskóti et al., 2012, 2013), vagy csak az ezekkel való elégedettségre (Lőrincz, Kövári, \& Banász, 2020), vagy mindkettőre (Insh \& Florek, 2010; Barreira, Guimarães, \& Panagopoulos 2017; Szabó, Tóth-Kaszás, Jakobi, \& Banász, 2019). Mi utóbbival értünk egyet, vagyis azzal, hogy - ha a település vezetése a szükös erőforrásait úgy kívánja felhasználni, hogy az a lakosok minél nagyobb megelégedésére szolgáljon, akkor - azokat a tényezőket érdemes fejleszteni, amelyek fontossága viszonylag nagy, viszont a velük való elégedettség viszonylag alacsony (Chen, Yang, Lin, \& Yeh, 2007). Az elégedettség mellett a fontosság felmérése Kano modellje szerint azért fontos, mert az egyes települési tényezők fejlesztése nem ugyanúgy járul hozzá az általános elégedettségükhöz (Horton \& Goers, 2019; Marien, 2013). Ez megfeleltethető a mikroökonómiából ismert közjószágok hasznos, káros vagy semleges voltának. Kano a hasznosságot több esetre bontotta, attól függően, hogy mit okoz a hiányuk: elégedetlenséget vagy semmit (nem érzik a hiányát). Ugyanakkor meg kell jegyeznünk, hogy a kevésbé fontos és jó elégedettséggel bíró területek között lehetnek olyan alapvető tényezők, melyek megszünése elégedetlenséget szülhet (Boley, McGehee, \& Hammet, 2017). A fontosság és elégedettség egyszerre való értékelésének hátránya, hogy a válaszadók ilyenkor hajlamosabbak az egyes tényezők fontosságát magasabbra értékelni, mint az azokkal való elégedettséget (Dwyer, Dragićević, Armenski, Mihalič, \& Knežević, 2016).

A későbbiekben bemutatott saját kutatásunkhoz hasonlóan, Koltai (2017) is vizsgálta korcsoportok szerint is a települési tényezőket. Magyarországra vonatkozóan azt állapította meg, hogy a fiatalabb korcsoportnak (20-39 évesek) sokkal fontosabb az internetelérés és a mobilhálózat minősége, mint a teljes minta átlagának, ellenben a település történelmét, hagyományait jóval alacsonyabbra értékelték, mint az átlag. A legidősebb korosztály (60 év felettiek) az átlagnál lényegesen alacsonyabbra értékelte az alábbi települési tényezők fontosságát: internetelérés, mobilhálózat minősége, a szabadidő eltöltésének lehetőségei.

A lakosság véleményének felmérése azért fontos, mert a földrajzi térségek, régiók, városok irányításában manapság egy jobban elötérbe kerülő irányvonal az a vállalatgazdaságtanból ismert tézis, mely szerint a szervezetek fö célja a kiváló szolgáltatásminőségen keresztül a vevői elégedettség hosszú távon való folyamatos biztosítása. A térségek, régiók, városok is hasonlóan müködnek, különféle szolgáltatásokat nyújtanak az ott élőknek, dolgozóknak és az oda érkező turistáknak - ők a szolgáltatások vevői, fogyasztói. Az általuk érzékelt elégedettség befolyásolhatja a térségbe való betelepülést, elvándorlást és turisztikai desztinációként az ideirányuló utazókedvet. A térségbe érkező turizmus pedig nemcsak a régió, hanem az ország gazdasági bevételeire is hatással van, föleg egy országos szinten olyan meghatározó turisztikai régió esetében, mint Magyarországon a Balaton térség. Ezen kívül olyan más, kemény gazdasági tényezőket is befolyásolhat a térség nagy vonzereje, mint például az ingatlanárak. Ezek emelkedéséhez vezet a megnövekedett ingatlankereslet, akár az állandó lakosé, akár a másodlagos otthonoké, nyaralóké, akár a befektetési célú ingatlanoké. Az ügyfél-orientáció, nevezetesen az ügyfelek igényeinek és elvárásainak megértése ugyanúgy, mint a vállalatgazdaságtanban az első lépés a település által nyújtott szolgáltatások minőségének javítása érdekében. A szolgáltatás minősége kritikus szerepet játszik a vállalatok közti versenyben, ez a földrajzi térségek között is érvényes lehet.

\section{A fontosság és elégedettség mátrixalapú vizsgálata}

A továbbiakban áttérünk a fontosság és elégedettség közti réselemzéssel kapcsolatos irodalmakra. A klasszikus fontosság-teljesítmény elemzést (Importance-Performance Analysis - IPA) Martilla és James (1977) dolgozta ki. A módszer az eredményeket a 2 . ábrán szemléltetett $2 \times 2$-es mátrixban ábrázolja.

2. ábra

\section{Az IPA/ISA mátrix sémája}

\begin{tabular}{c|c|c|}
\cline { 2 - 3 } fontosság magas & $\begin{array}{l}\text { I. Koncentráció } \\
\text { (Concentrate } \\
\text { here) }\end{array}$ & $\begin{array}{c}\text { II. Jó gyakorlat } \\
\text { fenntartás } \\
\text { (Keep up the }\end{array}$ \\
good work)
\end{tabular}

(ISA)

Forrás: Martilla \& James (1977) és Ramirez-Hurtado (2017) alapján saját szerkesztés

A klasszikus IPA megközelítés az elégedettséget két öszszetevő függvényében elemzi: a termék vagy szolgáltatás fontossága az ügyfelek számára (a 2. ábra függőleges tengelyén ábrázolva) és az általuk érzékelt teljesítménye (a 2. ábra vízszintes tengelyén). Így az IPA nem csupán egy elem teljesítményét értékeli, hanem annak fontosságát is a fogyasztó számára, ami meghatározó tényező az ügyfél elégedettsége szempontjából (Silva \& Fernandes, 2010). A későbbiekben terjedt el az ISA módszer (Importance-Satisfaction Analysis: fontosság-elégedettség elemzés) kifejezés, amikor egy tényező fontosságát nem annak teljesítményével veti össze, hanem a vele való elégedettséggel (a 2. ábra vízszintes tengelyén az elégedettséget mérik). $\mathrm{E}$ 
módszerek hasznos eszközök földrajzi területek (régiók, települések) vizsgálata esetén is.

A 2. ábrán jelzett minden negyedhez tartozik egy-egy kezelési javaslat, ajánlott stratégia:

I. Koncentráció: leginkább az e síknegyedbe kerülő tényezők fejlesztésére kell fókuszálni, mivel magas a fontosságuk, viszont alacsony a teljesítményük.

II. Jó gyakorlat fenntartása: a nagy jelentőségü és nagy teljesítményü szolgáltatáselemek szerepelnek itt, ezek a vizsgált terület nagy erősségei, amelyek színvonalának fenntartására kell törekedni.

III. Alacsony prioritás: alacsony teljesítményủ tényezök, amelyeknek a fontossága is alacsony. Az e negyedbe került tényezőkre nem éri meg további erőforrásokat fordítani, rájuk vonatkozóan költségcsökkentési és változáskezelési stratégiákat ajánlanak.

VI. Lehetséges túlterhelés: a kevésbé fontos, de jó teljesítményü tényezők kategóriája. Optimálisabb lenne más területekre irányítani az erőforrásokat például az első negyedben szereplő attribútumok felé (Abalo, Varela, \& Manzano, 2007; Nisco, Riviezzo, \& Napolitano, 2015; Martilla \& James, 1977; Minta \& Stephen, 2017; Riviezzo, Nisco, \& Napolitano, 2009). Boley et al. (2017) ugyanakkor megjegyzi, hogy óvatosan kell eljárni, mielőtt az erőforrásokat átadnánk a túlteljesítő funkcióktól, mivel ez csökkentheti az elégedettséget, hiszen itt olyan alapvető attribútumok szerepelhetnek, melyek jelenléte nem okoz elégedettséget, de eltűnésük elégedetlenséget eredményezhet. Joppe, Martin, \& Waalen (2001) szerint az itt szereplő tényezőket továbbra is fenn kell tartani, de nem feltétlenül kell további forrásokat elkülöníteni ennek érdekében.

Az IPA lehetővé teszi, hogy összehasonlítsuk egy attribútum fontosságát és teljesítményét (Oh, 2001). Fő célja diagnosztikai jellegű, azonosítja az alul- vagy felülteljesítő területeket (Abalo et al., 2007), és segít rangsorolni a javításra szoruló területeket (Shieh \& Wu, 2009), ezzel iránymutatást ad a vállalat jövőbeni erőforrás-elosztási döntéseire (Oh, 2001).

A módszer nagyon egyszerűnek és intuitívnek tủnik a fontosság és a teljesítmény mérésére, a szakirodalomban azonban számos megközelítés jelent meg a módszertani felvetések és lehetséges megoldások szempontjából, melyek érintik a következtetések levonását is. Három fő téma köré csoportosulnak a módszertani kérdések:

1. Milyen értékeket mérjünk a tengelyeken? (Átlag vagy medián?)

2. Mi legyen a tengelyek legkisebb és legnagyobb értéke? (A lehetséges vagy a tényleges válaszok skálája?)

3. Hol legyenek a mátrix alacsony és magas értékeit elválasztó kvadránsvonalak? (A tengelyeken felezőpontjánál vagy máshol?)
A vita tárgyát egyrészt az képezi, hogy a 2. ábra tengelyein a vélemények átlagát vagy mediánját mérjük. A szerzők többsége a változók átlagát használja (például Lopes \& Maia, 2012; Silva \& Fernandes, 2011; Ramirez-Hurtado, 2017), egyszerüsége és könnyen érthetősége miatt (Wade \& Eagles, 2003).

A viták másrészt a tengelyek terjedelméről szólnak. Kétféle megközelítés létezik, attól függően, hogy a használt skála (skálaorientált megközelítés), vagy az adatok (adatorientált megközelítés) értékeit jelölik (Riviezzo et al., 2009).

A viták harmadrészt arra terjednek ki, hogy a tengelyeken belül hogyan helyezkedjenek el a mátrix alacsony és magas értékeit elválasztó kvadránsvonalak. Általánosságban a tengelyek felezőpontjánál (mediánjánál) jelenítik meg ezeket, azonban más ajánlások is vannak erre vonatkozóan. Ramirez-Hurtado (2017) megállapította, hogy a modell egyik hátránya, hogy a tengelyeken az alacsony és magas értékeket elválasztó vonalak elhelyezése önkényes, ami megtévesztő lehet a javaslatok szempontjából. Martilla és James (1977) alapvető munkájukban a Likert-skála felezőpontjába javasolják elhelyezni a kvadránsvonalat. Silva \& Fernandes (2011) a medián használatát ajánlatosabbnak tartja az átlagnál, mivel véleményük szerint a Likert-skála nem valódi intervallumskála. Ugyanakkor Martilla és Carvey (1975) szerint az intervallumskála feltételezhető, különösen, ha az átlag- és a mediánérték következetesen észszerüen közel áll egymáshoz. A módszer alkalmazásának további korlátja az Oh (2001) által kifejtett úgynevezett „mennyezeti effektus”. A mennyezeti effektus amiatt lép fel, hogy a válaszadók hajlamosak magas fontosság és teljesítmény pontszámokat adni, és a túlértékelt pontszámok miatt a skálaorientált megközelítés alkalmazásakor a legtöbb attribútum a II. Jó gyakorlat fenntartása nevủ síknegyedbe esik. A „mennyezeti effektus" problémájának kiküszöbölésére az adatorientált megközelítést javasolják, a kvadránsvonalakat a mért fontossági és teljesítménymutatók átlagaira helyezve. Dwyer et al. (2016) is megállapítja, hogy ahhoz, hogy az IPA értelmezése megfelelö legyen, fontos a rácsvonalak elhelyezkedésének helyes megválasztása, ennek érdekében a kutatók többsége a fontossági és teljesítményértékek átlagát használja. Wade \& Eagles (2003) fontosság-teljesítmény mátrix alkalmazásáról szóló tanulmánya tetszőlegesnek, önkényesnek tartja az egyes negyedeket elválasztó vonalak elhelyezését. Kutatásukban a tanzániai turizmusra alkalmazva a módszert az volt a céljuk, hogy magasabb szintü, magas színvonalú szolgáltatási helyként pozícionálják magukat, ezért a rácsvonalakat a 4.0 értékre helyezték el az 1-től 5-ig terjedő Likert-skálán, hogy meg tudják különböztetni az IPA mátrix tengelyein a „rendkívül fontos” és a „kiváló teljesítmény” értékeit. Griffin \& Edwards (2012) szerint a mátrix belső rácsvonalai közül például a fontosság tengelyen lévő kvadránsvonalat akkor érdemes feljebb elhelyezni, ha például korlátozott a költségvetés, ezáltal csak a legnagyobb prioritással bíró kérdésekre van lehetőség koncentrálni.

Az IPA módszert kezdetben a piackutatás területén alkalmazták az ügyfelek elégedettségének elemzésére, 
valamint stratégiai marketingdöntések meghozatalának támogatására. A módszertan a döntéshozóknak segítséget nyújt célzott cselekvési programok kidolgozásában a versenyelőnyök elérése és fenntartása érdekében. Az egyik legszélesebb körben alkalmazott módszertani eszköz az idegenforgalom kutatásában (Boley et al., 2017). A mai napig hasznos és számos területen alkalmazott módszer (lásd 1. táblázat).

1. táblázat

\section{Az IPA módszer alkalmazása néhány empirikus} kutatásban

\begin{tabular}{|c|c|c|}
\hline \multirow{2}{*}{$\begin{array}{c}\text { Mire alkalmazták az IPA mód- } \\
\text { szert? }\end{array}$} & \multicolumn{2}{|l|}{ Szerző(k) } \\
\hline & név & év \\
\hline \multicolumn{3}{|c|}{$\begin{array}{l}\text { Az idegenforgalom, turizmus-, illetve } \\
\text { desztinációmenedzsment területén: }\end{array}$} \\
\hline $\begin{array}{l}\text { piaci szegmentáció támogatására } \\
\text { a turizmusmenedzsment terü- } \\
\text { letén }\end{array}$ & Wade \& Eagles & 2003 \\
\hline $\begin{array}{l}\text { a városi desztinációmenedzsment } \\
\text { támogatására }\end{array}$ & Griffin \& Edwards & 2012 \\
\hline $\begin{array}{l}\text { turisták elégedettségének elem- } \\
\text { zése }\end{array}$ & Nisco et al. & 2015 \\
\hline $\begin{array}{l}\text { egy turisztikai látványosság által } \\
\text { nyújtott szolgáltatások értéke- } \\
\text { lésére }\end{array}$ & $\begin{array}{l}\text { Pasaribu, Waryono, } \\
\& \text { Saputra }\end{array}$ & 2016 \\
\hline $\begin{array}{l}\text { desztinációk versenyképességé- } \\
\text { nek elemzésére }\end{array}$ & Dwyer et al. & 2016 \\
\hline $\begin{array}{l}\text { utazási irodai franchise rendsze- } \\
\text { rek értékelésére }\end{array}$ & Ramirez-Hurtado & 2017 \\
\hline \multicolumn{3}{|c|}{ Más tudományterületeken: } \\
\hline $\begin{array}{l}\text { városközpontok menedzsmentjé- } \\
\text { nek hatékonysági értékelésére }\end{array}$ & Riviezzo et al. & 2009 \\
\hline $\begin{array}{l}\text { egészségügyi szolgáltatások } \\
\text { menedzselésének segítésére }\end{array}$ & Lopes \& Maia & 2012 \\
\hline $\begin{array}{l}\text { a városi tömegközlekedés minö- } \\
\text { ségének vizsgálatára }\end{array}$ & $\begin{array}{l}\text { Hernandez, Mon- } \\
\text { zon \& de Ona }\end{array}$ & 2016 \\
\hline $\begin{array}{l}\text { a szolgáltatásminőség és az ügy- } \\
\text { fél-elégedettség elemzésére a } \\
\text { bankiparban }\end{array}$ & Minta \& Stephen & 2017 \\
\hline
\end{tabular}

Forrás: saját szerkesztés

A fontosság-elégedettség elemzés alapján nyert eredmények egyértelmű útmutatást nyújtanak a döntéshozóknak a beavatkozás fö területeinek meghatározására.

Az IPA/ISA mátrix továbbfejlesztése, az úgynevezett diagonális modell, amikor a mátrixban jelölik a 45 fokos átlót is. Ezen átló mentén a vizsgált tényezők fontosságával pontosan megegyezik annak teljesítménye (IPA), illetve az azzal való elégedettség (ISA). Az átló alatti tényezőkkel jobban elégedettek, mint amennyire fontosnak tartják azokat. Az átló feletti tényezők fontosabbak, mint amennyire elégedettek velük a lakosok. Minél nagyobb ezen átló feletti pontoknak az átlótól való vízszintes távolsága, annál nagyobb prioritással kell tekinteni rá a fejlesztendő területek kiválasztásakor (Ramirez-Hurtado, 2017).

\section{A kutatás módszertana}

A kutatáshoz felhasznált adatok primer kérdőíves felmérésből származnak, melyet a Pannon Egyetem Gazdaságtudományi Karán készítettek a balatoniak életminőségének felmérésére. „Balatoniak” alatt a Balaton kiemelt turisztikai fejlesztési térséghez kötődőket értjük. E több témakört átfogó kérdöívből jelen tanulmány tárgyát a lakosoknak a települési tényezőkről alkotott véleménye képezi, nevezetesen két kérdés kapcsán, melyek mindegyikére egy 1-től 5-ig terjedő Likert-skálán lehetett válaszolni: a Balaton térségbe tartozó településük kapcsán az egyes települési tényezők

a. mennyire fontosak Önnek (1: egyáltalán nem fontos, 5: nagyon fontos)?

b. mennyire elégedett ezekkel (1: egyáltalán nem vagyok elégedett, 5: teljes mértékben elégedett vagyok)?

A fontosságnak és az elégedettségnek is a megkérdezése összhangban van Chen et al. (2007) javaslatával, akik szerint csak ezek együttes felmérésével lehet a fejlesztések irányára javaslatokat adni a döntéshozók számára.

A vizsgált 27 települési tényezőt a szakirodalomban bemutatott tipikusan felmért tényezők (Koltai, 2005, 2015, 2016; Marien, 2012; Piskóti et al., 2012, 2013), valamint ajánlások (Lengyel, 2003) szerint határoztuk meg. Ezek öt kategóriába sorolhatók:

I. Települési adottságok: település természeti adottságai; település történelme, hagyományok, tradíciók.

II. Települési szolgáltatások: megközelíthetőség; infrastruktúra (pl.: gáz, víz, csatornázottság, utak állapota, közvilágítás); helyi tömegközlekedés; parkolási lehetőségek; járda megléte; kerékpárút megléte; közintézményekkel való ellátottság; egészségügyi ellátás, egészségügyi szolgáltatások; oktatási intézmények; lakókörnyezet állapota (pl.: zöldterületek, tisztaság, rendezettség); közbiztonság; nyugalom.

III. Gazdasági jellemzők: megélhetési költségek; kedvező ingatlanárak; munkalehetőségek; folyamatos fejlesztések a településen; vásárlási lehetőségek.

VI. Szabadidőhöz és turizmushoz köthető tényezők: pihenés, feltöltődés lehetőségei (wellness, amatőr sport); strandok; szórakozási lehetőségek, éjszakai élet; éttermek, vendéglátás; kulturális programok választéka; látnivalók (mennyisége és minősége).

V. Demográfiai tényezők: lakosság korösszetétele, etnikai összetétele; emberi (családi, baráti) kapcsolatok, közösség megléte; lakosság barátságossága.

A 2018 és 2019-ben (online és papír alapon) végzett felmérés 1201 fös értékelhető mintát eredményezett. Az első kérdőíves megkérdezés 2018 nyarán zajlott, a kitöltött kérdőívek száma 844 volt, amit 2019 nyarán 1201-re si- 
került növelni. Az adatgyüjtés során egyetemi hallgatókon és oktatókon, kutatókon kívül, önkormányzatokat is megkértünk a kérdőív terjesztésére. Az adatfelvétel papír alapon és online történt, önkényes és hólabda mintavételi eljárással. Bár a vizsgált populáció nagysága tükrében a kutatás erőforrásai nem tették lehetővé a reprezentatív felmérést, eredményeinket mégis relevánsnak találjuk, mivel a két nyáron történt megkérdezés eredményei nem mutattak szignifikáns eltérést.

A kutatás előzményének tekinthető korábbi tanulmányunkban (Fekete-Berzsenyi, 2019; Fekete-Berzsenyi \& Banász, 2020) bemutattuk az átlagok alapján a teljes minta véleményét arról, hogy mennyire elégedettek az egyes települési tényezőkkel, azok fontosságához képest. Jelen tanulmányban ismertetjük a felmérésünk eredményét életkor szerinti bontásban is. Feltételeztük, hogy azt, hogy valaki mennyire tartja fontosnak az egyes települési tényezőket, illetve mennyire elégedett ezekkel, a demográfiai tényezők közül befolyásolhatja az emberek neme, végzettsége, életkora is. A 2. táblázatban összefoglalt 162 darab kapcsolatvizsgálatot végeztük el, a névleges skálán mérhető nemek esetében a Cramer mutatóval (mivel aszszociációs kapcsolatok erősségét mérő mutató szükséges), a sorrendi skálán mérhető végzettség és az életkor esetén a Kendall-féle tau mutatóval (mivel ez alkalmas a rangkorrelációs kapcsolatok erősségének mérésére). A Cramer mutató 0-1 közti értéket vehet fel, a Kendall-féle tau -1 és 1 között mozog. Abszolút értékeik minél közelebb vannak 1-hez, annál erősebb kapcsolatot jeleznek.

Amiatt döntöttünk úgy, hogy a későbbi elemzéseinket életkor szerinti bontásban fogjuk elvégezni, mivel a 2. táblázat utolsó - eredményeket összegző - sorai azt mutatják, hogy a fontosság és az elégedettség az életkorral áll a legtöbb esetben szignifikáns kapcsolatban. Továbbá, a telepü-

Kapcsolatvizsgálatok: települési tényezők vs. demográfia

\begin{tabular}{|c|c|c|c|c|c|c|}
\hline & \multicolumn{6}{|c|}{ Potenciális magyarázó változók } \\
\hline & \multicolumn{2}{|c|}{ Nem } & \multicolumn{2}{|c|}{ Végzettség } & \multicolumn{2}{|c|}{ Életkor } \\
\hline & $\mathrm{F}$ & E & $\mathrm{F}$ & E & $\mathrm{F}$ & $\mathrm{E}$ \\
\hline Megközelíthetőség & 0,105 & 0,081 & & 0,062 & 0,049 & \\
\hline Infrastruktúra & 0,088 & 0,080 & & & 0,060 & $-0,055$ \\
\hline Helyi tömegközlekedés & 0,101 & 0,093 & $-0,167$ & & $-0,095$ & \\
\hline Parkolási lehetőségek & 0,089 & & & 0,074 & & \\
\hline Járda megléte & 0,109 & 0,100 & & & & $-0,169$ \\
\hline Kerékpárút megléte & & & 0,097 & 0,108 & 0,086 & \\
\hline Település természeti adottságai & 0,097 & 0,089 & 0,136 & 0,134 & 0,186 & 0,122 \\
\hline Település történelme, hagyományok, tradíciók & & & & & 0,200 & 0,056 \\
\hline Közintézményekkel való ellátottság & & & $-0,077$ & 0,060 & 0,062 & \\
\hline Egészségügyi ellátás & 0,091 & & & & & 0,053 \\
\hline Oktatási intézmények & 0,105 & & $-0,085$ & 0,064 & $-0,076$ & \\
\hline Vásárlási lehetőségek & 0,108 & 0,091 & $-0,081$ & & & \\
\hline Megélhetési költségek & 0,097 & & $-0,125$ & & & \\
\hline Kedvező ingatlanárak & & & & & & 0,067 \\
\hline Folyamatos fejlesztések a településen & 0,087 & 0,094 & 0,065 & & 0,149 & $-0,117$ \\
\hline Munkalehetőségek & 0,099 & 0,114 & $-0,110$ & & $-0,082$ & $-0,099$ \\
\hline Pihenés, feltöltődés lehetőségei & 0,087 & & 0,074 & 0,085 & & \\
\hline Szórakozási lehetőségek, éjszakai élet & & 0,088 & $-0,123$ & & $-0,203$ & \\
\hline Kulturális programok választéka & & & 0,064 & & 0,097 & \\
\hline Látnivalók mennyisége és minősége & 0,089 & & & 0,058 & & \\
\hline Éttermek, vendéglátás & 0,094 & 0,083 & & & & $-0,100$ \\
\hline Lakosság korösszetétele, etnikai összetétele & & & & 0,101 & 0,081 & 0,057 \\
\hline Emberi kapcsolatok, közösség & & & 0,057 & 0,128 & 0,093 & \\
\hline Lakosság barátságossága & & & & 0,082 & 0,127 & \\
\hline Lakókörnyezet állapota & & & 0,104 & 0,065 & 0,124 & $-0,076$ \\
\hline Közbiztonság & & & 0,107 & 0,134 & 0,138 & 0,063 \\
\hline Nyugalom & & & 0,075 & & 0,150 & \\
\hline Legnagyobb érték: & 0,109 & 0,114 & 0,167 & 0,134 & 0,203 & 0,169 \\
\hline \multirow{2}{*}{ Szignifikáns kapcsolatok száma: } & 15 & 10 & 16 & 13 & 18 & 12 \\
\hline & \multicolumn{2}{|c|}{25} & \multicolumn{2}{|c|}{29} & \multicolumn{2}{|c|}{30} \\
\hline
\end{tabular}

Rövidítések: F: fontosság, E: elégedettség.

Üres cellák: nem szignifikáns kapcsolatok.

Háttérszínek (a szignifikáns kapcsolatok esetén): a sötétebb háttérszín erősebb kapcsolatot jelez.

Forrás: saját kutatás 
lési tényezőknek mind a fontossága, mind az ezekkel való elégedettség az életkorral állt legerősebb kapcsolatban. A kérdőívben mindenki maga írhatta be az életkorát. A válaszolók fele 37 évnél fiatalabb volt, emiatt két életkor-kategóriára bontottuk a mintát: legfeljebb 37 évesek, 37 évnél idősebbek. Az eredményeket minden válaszolóra, továbbá erre a két korcsoportra fogjuk bemutatni.

A kutatás módszereként a réselemzés elvégzésére a fontosság-elégedettség (ISA) elemzést alkalmazzuk, melynek eredményeit diagonális mátrixban szemléltetjük.

A szakirodalmi részben ismertettük a fontosság-elégedettség mátrixszal kapcsolatos három fő vitakérdést: az átlag vagy a medián szerepeljen a mátrix tengelyein, mekkora legyen a tengelyek terjedelme, illetve a kvadránsvonalak hol legyenek elhelyezve a tengelyeken?

A tengelyeken az átlagokat fogjuk szerepeltetni, két ok miatt. Egyrészt, mert a szakirodalmi fejezetben is említettük, hogy a kutatók többsége is ezt használja, másrészt mert a medián (vagy akár) a módusz (azaz a leggyakrabban előforduló, tipikus válasz) alapján kevésbé tudnánk megkülönböztetni az egyes települési tényezőkről alkotott véleményt. Ennek oka, hogy a 27 települési tényező fontossága, illetve az ezekkel való elégedettség kapcsán vizsgálható $(27 \times 2=) 54$ indikátor közül a fiatalabbak és idősebbek véleményének módusza (az 1-5 skálán adott leggyakoribb válaszuk) 41 esetben megegyezett, a medián (az 1-5 skálán adott válaszok közül az az érték, amelynél kevesebb pontszámot adott a válaszolók fele) pedig 39 esetben. A válaszok átlaga viszont mind az 54 indikátor esetében más, így jobban differenciálható a két korcsoport véleménye is.

A tengelyek terjedelme kapcsán a mátrixokat elkészítjük a szakirodalomban említett skála- és adatorientált megközelítés szerint is, vagyis úgy, hogy a tengelyeken a teljes Likert-skála legyen látható 1-től 5-ig (skálaorientált megközelítés), illetve kinagyított változatban is, amikor a tengelyeken csak az adatok látszódnak (adatorientált megközelítés).

A kvadránsvonalakat minden esetben a tengelyek felezőpontjánál helyezzük el.

\section{Kutatási eredmények}

A települési tényezőkkel kapcsolatos kérdések esetén a válaszadási hajlandóság viszonylag magas volt. Az egyes települési tényezők fontosságára a minta 7-13\%-a nem válaszolt, az elégedettség esetén pedig $8-23 \%$ nem jelölte be véleményét.

A válaszok móduszát, azaz a tipikus, leggyakoribb válaszokat tekintve elmondható, hogy a válaszadók tipikusan minden települési tényezőt fontosnak vagy nagyon fontosnak ítéltek, azaz az 1-től 5-ig terjedő skálán a 4-es, illetve az 5-ös értékeket jelölték legtöbben. A 27 tényező közül csak 5-öt értékeltek 4-esre, ezek: a település történelme, hagyományok, tradíciók; a szórakozási lehetőségek, éjszakai élet; a kulturális programok választéka; a látnivalók mennyisége és minősége; valamint a lakosság korösszetétele, etnikai összetétele.

Az elégedettségre adott leggyakoribb válaszok válto- zatosabb képet mutatnak, bár itt is azt látni, hogy inkább elégedettek a lakosok, mint elégedetlenek. Legrosszabb esetben is közepesre (3-asra) értékelték az elégedettségüket. Kilenc tényező kapcsán adták ezt az értékelést, ami azt jelenti, hogy a többség ezekkel a legelégedetlenebb: helyi tömegközlekedés; parkolási lehetőségek; egészségügyi ellátás, egészségügyi szolgáltatások; vásárlási lehetőségek; megélhetési költségek; kedvező ingatlanárak; folyamatos fejlesztések a településen; munkalehetőségek; szórakozási lehetőségek, éjszakai élet.

Csak 3 olyan tényező volt, amellyel a többség maximálisan (5) elégedett, mégpedig: megközelíthetőség, település természeti adottságai, nyugalom. A maradék 15 tényezőt 4-esre értékelték, azaz inkább elégedettek velük, mint elégedetlenek.

A 3. ábra szemlélteti a válaszok átlagait. Csak az ábra felső részére (az I. és II. kvadránsba) kerültek adatok, vagyis a válaszok átlagát tekintve minden települési tényezőt inkább fontosnak tartanak, mint kevésbé fontosnak. Elégedettség tekintetében csak két tényezővel elégedetlenebb az átlag balatoni, mint elégedett: az ingatlanárakkal és a szórakozási lehetőségekkel. Csak ez a két tényező került az I. síknegyedbe, amely esetén a szakirodalom azt javasolja, hogy ezek fejlesztésére kell leginkább koncentrálni. Az összes többi 25 települési tényező a II. síknegyedben található, azaz már jelenleg is jó gyakorlatnak minősülnek, szintjük fenntartása ajánlott a szakirodalom alapján.

3. ábra

Települési tényezők: átlagos fontosság vs. elégedettség, skálaorientált megközelítés

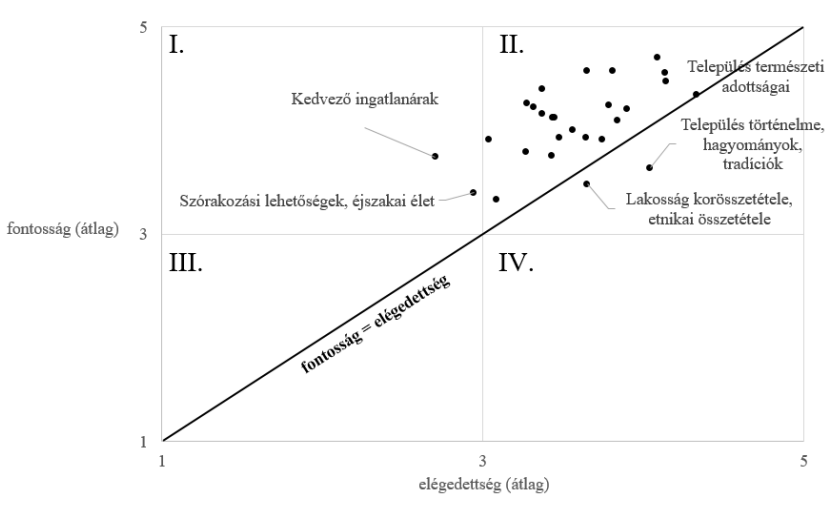

Forrás: saját kutatás

Majdnem a 45 fokos átló mentén helyezkednek el a település természeti adottságai, azaz e tényezővel való elégedettség megegyezik annak fontosságával. Az átló alatt csak két tényező látható, e két tényezővel elégedettebbek, mint amennyire fontosnak tartják ezeket: a település történelme, hagyományok, tradíciók, valamint a lakosság korösszetétele, etnikai összetétele. Az összes többi (24) tényezővel kevésbé elégedettek, mint amennyire fontosnak tartják öket. A 3. ábra kinagyított változata korábbi tanulmányunkban található (Fekete-Berzsenyi \& Banász, 2020). Az eredmények összhangban vannak Oh (2001) említett „,mennyezeti effektusával”, miszerint a túlértékelt pontszámok miatt a skálaorientált megközelítés alkalma- 
zásakor (amikor a tengelyeken a teljes, 1-től 5-ig terjedő Likert-skálát szemléltetjük) a legtöbb attribútum a II. Jó gyakorlat fenntartása nevü síknegyedbe esik. Mivel e probléma kiküszöbölésére a szakirodalom az adatorientált megközelítést javasolja, a további ábrákon a tengelyek terjedelme csak az adatok terjedelmével lesz egyenlö.

A 4. és az 5. ábra a 3. ábrát bontja meg a fiatalabbak (4. ábra) és az idősebbek (5. ábra) véleményére, adatorientált megközelítésben szemléltetve.

\section{A fiatalabbak (legfeljebb 37 évesek) átlagos véleménye a települési tényezőkről, adatorientált megközelítés}

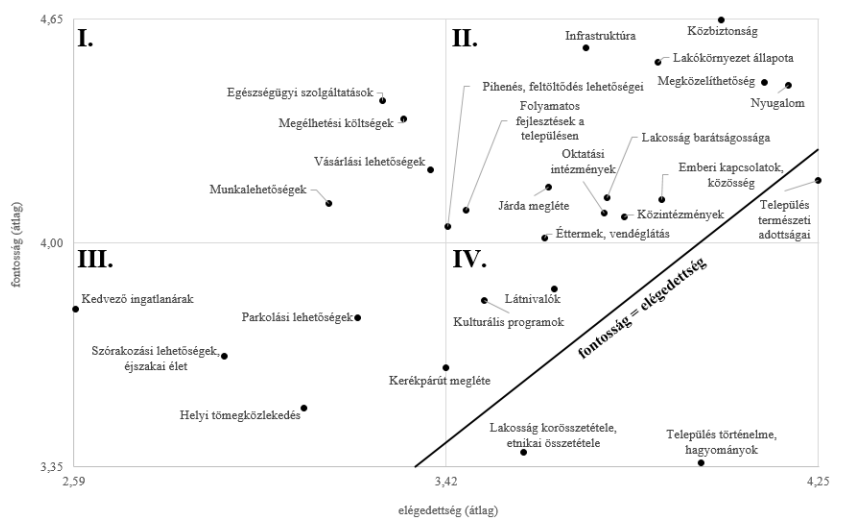

Forrás: saját kutatás

Az idősebbek (37 évnél idősebbek) átlagos véleménye a települési tényezőkről, adatorientált megközelítés

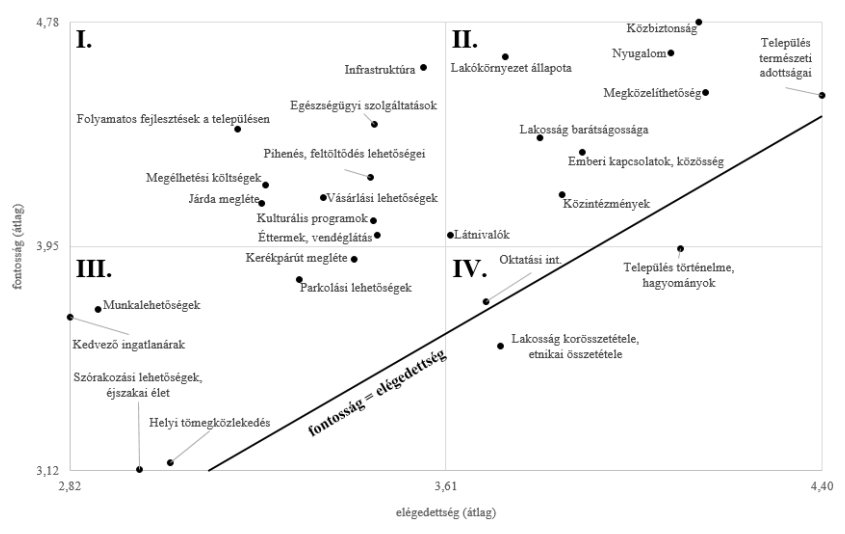

Forrás: saját kutatás

A 4. és 5. ábrákon berajzolt átlók mentén a tényező fontossága egyenlő a vele való elégedettséggel. Ez a fiatalabbaknál a település természeti adottságai esetében tapasztalható leginkább, az idősebbeknél pedig az oktatási intézmények esetében. Az ábra átló alatti részén lévő tényezőkkel elégedettebbek a balatoniak, mint amennyire fontosnak tartják őket. Elsősorban nem ezek fejlesztésébe érdemes beruházni, viszont szinten tartásuk indokolt annak érdekében, hogy továbbra is inkább elégedettebbek legyenek velük a lakosok, azok fontosságához képest. Mindkét korosztálynál ide tartozik az a két tényezö, amely a korcsoportokra való bontás előtt is idekerült (a 3. ábrán): egyrészt a település történelme, hagyományok, tradíciók, másrészt a lakosság kor- és etnikai összetétele. Ezeken felül a fiatalabbak még a település természeti adottságaival is nagyobb mértékben elégedettek, mint amennyire fontosnak tartják.

A települési tényezők többsége az átló felett található, vagyis elégedetlenebbek velük, mint amennyire fontosnak tartják őket. Minél nagyobb a települési tényezőt jelző pontnak az átlótól vett vízszintes távolsága, annál inkább elégedetlenek az adott tényezővel, annak fontosságához képest. A szakirodalom (hivatkozások) alapján azon tényezők fejlesztésére érdemes elsősorban fókuszálni, amelyeknek az átlótól vett vízszintes távolsága a legnagyobb.

Az a terület, ami a módszertan alapján leginkább fejlesztésre ajánlatos (az I. koncentráció nevü negyed területe) eltéröképpen alakul a két korosztálycsoportban (a 4. és az 5. ábrán). A 37 évnél fiatalabbaknál az egészségügyi szolgáltatások, a megélhetési költségek, a vásárlási lehetőségek és a munkalehetőségek tartoznak ide. Az idősebb korosztályba tartozóknál a fiatalabbaknál említett tényezők kiegészülnek még az infrastruktúra, folyamatos fejlesztések a településen, pihenés és feltöltődés lehetőségei, járda megléte, kulturális programok, éttermek és vendéglátás tényezőkkel. Ezen változók mindegyike a kulturális programok kivételével a fiatalabb korosztálynál a II. jó gyakorlat fenntartása nevü negyedben szerepel.

Számszerüsítettük, hogy a két életkorcsoport véleménye mennyivel tér el a teljes (1201 fös) minta átlagától. Mivel az 1-5 skálán mért válaszok korcsoportonként számított átlagai csak legfeljebb 0,3-del tértek el a teljes minta átlagától, ezért az eltérések nagysága helyett azok előjelére fókuszálunk. A 3. táblázat tartalmazza az eredményeket, vagyis azt, hogy a teljes mintán számolt eredményekhez képest a fiatalok, illetve az idősebbek esetén hogyan módosul az egyes települési tényezők fontossága és az ezekkel való elégedettségérzetük.

A 3. táblázat alapján a következő megállapítások tehetők a fiatalabbak és idősebbek véleményéröl, a teljes minta összegzett véleményéhez képest.

A táblázat $A$ ) részébe került 7 települési tényező az, amely a fiataloknak fontosabb és elégedettebbek velük. Ugyanez a 7 tényező az idősebbek számára kevésbé fontos és kevésbé is elégedettek velük. A táblázat $\mathrm{B}$ ) részében az a 3 tényező található, amelyek a fiataloknak fontosabbak, de kevésbé elégedettek velük. Erre a 3 tényezőre ellentétes megállapítások tehetők az idősebbek esetén: ezek az idősebbeknek kevésbé fontosak, viszont elégedettebbek velük, mint a teljes minta.

A táblázat C) részében 6 olyan tényező található, amely a fiataloknak kevésbé fontos, viszont elégedettebbek velük, míg az idősebbeknek fontosabb és kevésbé elégedettek ezekkel. Mindemellett mindkét korcsoport számára van még egy tényező, amivel a fiatalok ugyanúgy elégedettebbek, az idősebbek pedig kevésbé, azonban a fontosság tekintetében nem állítható egységesen mindkét korosztályról az, hogy a fiataloknak kevésbé fontos, és az 
idősebbeknek lenne fontosabb. A fiataloknak kevésbé fontosabb az emberi (családi, baráti) kapcsolatok, közösség megléte. Az idősebbeknek fontosabb a kerékpárút megléte. még nem vizsgálták korcsoportonként a lakosoknak a települési tényezőkről alkotott véleményét.

A felmérésünk során feltett kérdések meghatározásakor figyelembe vettük az eddigi magyarországi és nemzetkö-

Átlagos fontosság és elégedettség, fiatalabbak vs. idősebbek

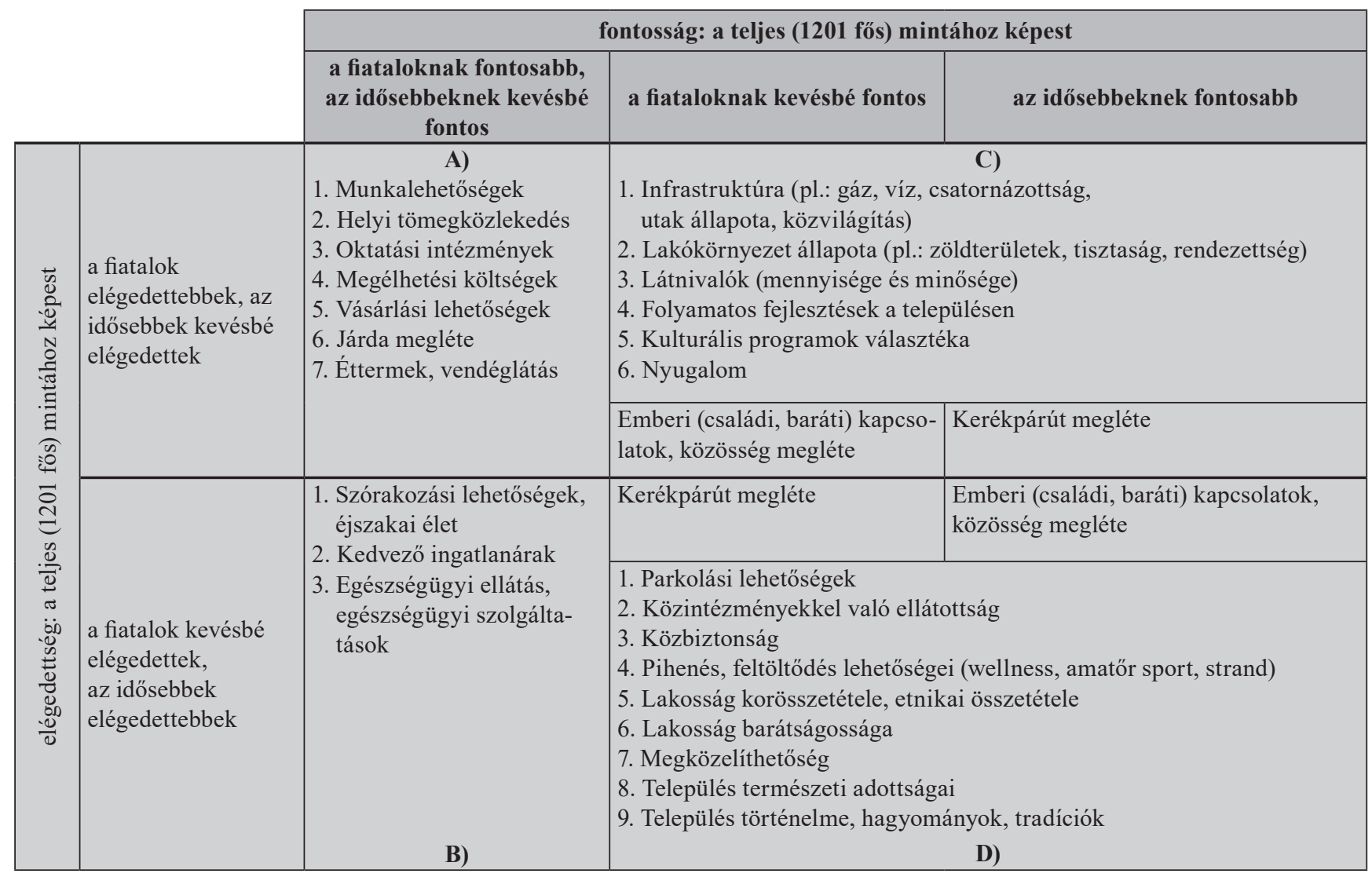

A táblázat D) részébe sorolódott a legtöbb tényező. Közülük kilencről állíthatjuk azt, hogy a fiataloknak kevésbé fontos, és kevésbé elégedettek velük, az idősebbek pedig fontosabb és elégedettebbek is ezekkel. A 10. tényezőben nem fed át a két korosztály. E tényező a $\mathrm{C}$ ) résznél említett kivétellel egyezik meg: az idősebbeknek az emberi kapcsolatok fontosabbak, mint a teljes mintára számolt átlag, a fiataloknak pedig a kerékpárút kevésbé fontos, mint az összesített mintának.

\section{Összefoglalás, következtetések}

Kutatásunkban azt vizsgáltuk, hogy melyek azok a települési tényezők, amelyeket a Balaton térség lakossága fontosnak tart, és azokkal mennyire elégedett - tettük mindezt a fiatalabb és az idősebb korosztály szemszögéből. Eredményeink abból a szempontból újszerűek, hogy a viszonylag fiatal (2016 decemberében meghatározott) Balaton kiemelt turisztikai fejlesztési térségben (GOV, 2016) zi kutatásokat annak tekintetében, hogy tipikusan milyen települési tényezők képezték az eddigi megfigyelések tárgyát, mindezt természetesen Lengyel (2003) ajánlása alapján a régió speciális karakterisztikájához alakítva. Számos szerző (Chen, Yang, Lin, \& Yeh, 2007; Insh \& Florek, 2010; Marien, 2013; Barreira, Guimarães, \& Panagopoulos, 2017; Horton \& Goers, 2019; Szabó, Tóth-Kaszás, Jakobi, \& Banász, 2019) javallata alapján a fontosság és az elégedettség szimultán értékelése mellett döntöttünk.

A települési tényezők fontosságának értékelése során a Balaton térségre vonatkozó eredményeink több tényező esetén egybevágnak Koltai (2017) országos felmérésen alapuló megállapításával. Ilyen egyrészt a közbiztonság kimagasló fontossága, amely a mi eredményeinkben is a legfontosabb tényezőként jelent meg mindkét vizsgált korosztály számára. Másik, Koltaihoz (2017) hasonló megállapításunk, hogy a fiatalabb korosztálynak kevésbé fontos a település történelme, hagyományai. A szabadidő eltöltésének lehetőségei témakörben Koltaihoz (2017) csak 
részben hasonló eredményeket kaptunk, aki szerint a fiatalabbaknak ezek fontosabbak. Kérdöívünkben több kérdés is érintette a szabadidő témakörét: pihenés, feltöltődés lehetőségei (wellness, amatőr sport, strand); szórakozási lehetőségek, éjszakai élet; kulturális programok választéka; a látnivalók száma, színvonala. Ezek közül mi csak a szórakozási lehetőségek, éjszakai élet tényező esetén tapasztaltuk azt, hogy fontosabb a fiatalabbak számára.

Az eredmények bemutatásának eszköze az ISA mátrix volt, melynek egyes negyedeiben konkrét cselekvési tervek fogalmazhatók meg. A módszertan szerint az I. (koncentráció) negyed területére eső települési tényezőket érdemes fejleszteni, mivel az ide kerülő tényezők fontosak a megkérdezett lakossági kör számára, ugyanakkor az adott tényezővel való elégedettségük alacsony. Kutatási eredményeink tükrében ezzel kapcsolatban a következő megállapításokat tesszük a fiatalabb és az idősebb korosztályra vonatkozóan. Mindkét korosztály számára fontos lenne a következő három tényező fejlesztése: egészségügyi szolgáltatások, megélhetési költségek, vásárlási lehetőségek. A fiatalabb korosztály (legfeljebb 37 évesek) esetében még a munkalehetőségek tartoznak e kategóriába. Az idősebb korosztály (37 évnél idősebbek) esetében további hat települési tényező szerepel a fejlesztésre ajánlott területek között, ezek: infrastruktúra (pl.: gáz, víz, csatornázottság, utak állapota, közvilágítás), folyamatos fejlesztések a településen, pihenés és feltöltődés lehetőségei, járda megléte, kulturális programok, éttermek és vendéglátás.

Az ISA módszertan megfelelö és könnyen értelmezhető eszközt ad a helyi, regionális döntéshozók kezébe annak érdekében, hogy a rendelkezésre álló szükös fejlesztési forrásokat azokra a területekre irányítsák, melyek fontosak a megcélzott lakossági kör számára. Az elégedettség és fontosság közti rés nagyságának ismerete a fejlesztési források elosztása feletti döntések meghozatala során hasznos ismeretekkel szolgálhat arra vonatkozóan, hogy a Balaton térség lakossága miként priorizálja a települési tényezők fejlesztését. Kutatásunk eredményei között számos olyan tényező szerepel, melyekre a döntéshozóknak ráhatásuk lehet, és ezek közül külön is kiemelnénk azokat, melyek fejlesztése a régió turisztikai jellege miatt is nagyon hangsúlyos lehet. Ezek, a helyi lakosok véleménye szerint fejlesztendö területek, melyek a turizmust is befolyásolhatják: vásárlási lehetőségek, infrastruktúra, pihenés és feltöltődés lehetőségei, járda megléte, kulturális programok, éttermek és vendéglátás. Ezen tényezők fejlesztése nélkülözhetetlen ahhoz, hogy az idelátogatók jól érezzék magukat, ezáltal további utazásokat indukálva.

\section{Jelen kutatás korlátai és lehetséges jövőbeni kutatási irányok}

Kutatásunk korlátai között említhető a vizsgált minta nem reprezentatív jellege. Ennek ellenére a nagy mintánk eredményeit hasznosnak tartjuk, mivel a két év (2018 és 2019) nyarán végzett mintavétel során nem mutatkozott szignifikáns különbség a fontosság és elégedettség átlagokban.

Mi több, érdemesnek tartanánk a közeljövőben újra elvégezni a kérdőívezést. Olyan érdekes kérdésekre keres- nénk a választ, hogy a COVID-19 járvány hatására vajon már az I. síknegyedbe kerülnének a fiatalabb korosztály számára is az egészségügyi szolgáltatások, illetve az idősebbek számára a munkalehetőségek?

További korlátként említhető, hogy a helyi döntéshozók nem tudnak befolyásolni minden, a tanulmányban szereplő tényezőt, például a lakosság barátságosságát. A települési tényezők fontossága, illetve az ezekkel való elégedettség nem csak életkor szerint különbözhet. További kutatási irányként érdekes lenne megvizsgálni az eredményeket végzettség szerint, vagy településtípusonként (partmenti vs. nem partmenti településeken élők, községben vs. városban élők véleménye), vagy a településhez való kötődés jellege szerint (helyi lakosok vs. csak nyaralóval rendelkezők).

Eredményeink inspirációként szolgálhatnak a döntéshozó szakemberek számára, hogy a szűkös erőforrások elosztásakor melyek azok a területek, melyek a Balaton térség lakossága számára fontosak és kevésbé elégedettek velük. Mindezt könnyen értelmezhető mátrix formában vizualizáltuk. A felhasznált ISA mátrix módszertani dilemmái a téma iránt érdeklődő kutatói közösség számára lehet gondolatébresztő.

\section{Felhasznált irodalom}

Abalo, J., Varela, J., \& Manzano, V. (2007). Importance values for importance-performance analysis: A formula for spreading out values from preference rankings. Journal of Business Research, 60(2), 115-121. https://doi.org/10.1016/j.jbusres.2006.10.009

Barreira, A. P., Guimarães, M. H., \& Panagopoulos, T. (2017). What Is More Important to Residents: A City's Attractiveness or Citizens' Residential Satisfaction? An Analysis of the Explanatory Attributes in Shrinking Cities of Portugal. In New Dimensions in Community Well-Being (pp. 129-151). Cham: Springer. https://doi.org/10.1007/978-3-319-55408-2_7

Boley, B., McGehee, N., \& Hammet, A.L. (2017). Importance-performance analysis (IPA) of sustainable tourism initiatives: The resident perspective. Tourism Management, 58(Febr), 66-77. https://doi.org/10.1016/j.tourman.2016.10.002

Chen S., Yang C., Lin W., \& Yeh T. (2007). Service quality attributes determine improvement priority. The TQM Magazine, 19(2), 162-175. https://doi.org/10.1108/09544780710730005

Dwyer, L., Dragićević, V., Armenski, T., Mihalič, T., \& Knežević, C. L. (2016). Achieving Destination Competitiveness: an Importance - Performance Analysis of Serbia. Current Issues in Tourism, 19(13), 1309-1336. https://oi.org/10.1080/13683500.2014.944487

Fekete-Berzsenyi, H. (2019). A Balaton térsége mint élettér III.: Települési tényezők - fontosság vs. elégedettség. In Sulyok, J., Banász, Zs., Fehérvölgyi, B., Hiezl, K. \& Szabó, R. (Eds.), „Mi, balatoniak...” A Balatoni Turisztikai Kutatóintézet tanulmánykötete (pp. 77-82). Veszprém: Pannon Egyetemi Kiadó. https://www.gtk. uni-pannon.hu/wp-content/uploads/2019/11/batuki_ tanulmanykotet_2018_nyomda-v3.pdf 
Fekete-Berzsenyi, H., \& Banász, Zs. (2020). Települési tényezők a Balaton régióban - 2018 és 2019 nyarán végzett fontosság vs. elégedettség felmérés eredményei. Comitatus, 30(235), megjelenés alatt.

Griffin, T., \& Edwards, D. (2012). Importance - performance analysis as a diagnostic tool for urban destination managers. An International Journal of Tourism and Hospitality Research, 23(1), 32-48.

http://dx.doi.org/10.1080/13032917.2011.653630

GOV (2016). 429/2016 (XII. 15.) Korm. rendelet a turisztikai térségek és a kiemelt turisztikai fejlesztési térségek meghatározásáról. https://net.jogtar.hu/jogszabaly?docid $=$ A1600429.KOR\&txtreferer $=00000001 . T X T$

GOV (2000). 2000. évi CXII. törvény a Balaton Kiemelt Üdülökörzet Területrendezési Tervének elfogadásáról és a Balatoni Területrendezési Szabályzat megállapításáról. https://mkogy.jogtar.hu/jogszabaly?do$\mathrm{cid}=\mathrm{a} 0000112 . \mathrm{TV}$

Hernandez, S., Monzon, A., \& de Oña, R. (2016). Urban transport interchanges: A methodology for evaluating perceived quality. Transportation Research Part A: Policy and Practice, 84(Febr), 31-43.

https://doi.org/10.1016/j.tra.2015.08.008

Horton, G., \& Goers, J. (2019). A Revised Kano Model and its Application in Product Feature Discovery [on-line]. https://www.researchgate.net/publication/332304132_A_Revised_Kano_Model_and_its_ Application_in_Product_Feature_Discovery

Insch, A., \& Florek, M. (2010). Place Satisfaction of City Residents: Findings and Implications for City Branding. In Ashworth, G., Kavaratzis, M., \& Elgar, E. (Eds.), Towards Effective Place Brand Management (pp. 191-204). Cheltenham, Northamton: Edward Elgar.

https://doi.org/10.4337/9781849806398.00017

Joppe, M., Martin, D. W., \& Waalen, J. (2001). Toronto's image as a destination: a comparative importance - satisfaction analysis by origin of visitor. Journal of Travel Research, 39(3), 252-260. https://doi.org/10.1177/004728750103900302

Koltai, Z. (2005). A magyarországi városok versenyképességének lakossági megítélése. Tér és Társadalom, 19(3-4), 23-41. https://doi.org/10.17649/tet.19.3-4.1017

Koltai, Z. (2015). Településtípusok lakóhelyi vonzerőinek értékelése. Földrajzi Közlemények, 139(3), 213-225. https://foldrajzitarsasag.hu/downloads/foldrajzi_kozlemenyek_2015_139_evf_3_pp_213.pdf

Koltai, Z. (2016). Városok vonzereje országos és regionális léptékben. In Lengyel, I. \& Nagy, B. (Eds.), Térségek versenyképessége, intelligens szakosodása és újraiparosodása (pp. 272-289). Szeged: JATEPress. http://eco.u-szeged.hu/download.php?docID=59335

Koltai, Z. (2017). A települési vonzerők magyarországi megítélése. Assessment of the attractions of the residential place in Hungary. Közép-Európai Közlemények, 10(3), 91-106. http:// vikek.eu/wp-content/uploads/2017/12/KEKNo382017.3.sz\%C3\%A1m.pdf
KSH (2020). A kereskedelmi szálláshelyeken eltöltött vendégéjszakák turisztikai régiónként. http://www. $\mathrm{ksh} . \mathrm{hu} /$ docs/hun/xstadat/xstadat_evkozi/e_oga006a. html?back=/stadat ksz

Lengyel, I. (2003). Verseny és területi fejlödés: térségek versenyképessége Magyarországon. Szeged: JATEPress.

Lopes, S. D. F., \& Maia, S. C. F. (2012). Applying importance-performance analysis to the management of health care services. China-USA Business Review, 11(2). https://doi.org/10.17265/1537-1514/2012.02.010

Lőrincz, K., Kővári, E. M., \& Banász, Zs. (2020). Miért jó Szentesen élni? - Egy hazai kisváros lakosságának életminősége és helyi kötődése. Földrajzi Közlemények, 144(1), 112-131. https://doi.org/10.32643/fk.144.1.8

Marien, A. (2012). A sikeres településmarketing kulcsa az elégedett lakosság. In Piskóti, I. (ed.), Marketingkaleidoszkóp (pp. 91-96). Miskolc: Miskolci Egyetem. http://www.marketing-turizmus.hu/otka/n33.pdf

Marien, A. (2013). A lakossági elégedettség és a helyben maradást magyarázó tényezők összefüggései. Marketing \& Menedzsment, 47(1), 3-10. http://www.marketing-turizmus.hu/otka/01.pdf

Martilla, J. A., \& Carvey, D. W. (1975). Four subtle sins in marketing research. Journal of Marketing, 39(1), 8-15. https://doi.org/10.2307/1250797

Martilla, J. A., \& James, J. C. (1977). Importance-Performance Analysis, The Journal of Marketing, 41(1), 77-79. https://doi.org/10.2307/1250495

Minta, N. K., \& Stephen, O. (2017). Importance-Performance Matrix Analysis (IPMA) of Service Quality and Customer Satisfaction in the Ghanaian Banking Industry. International Journal of Academic Research in Business and Social Sciences, 7(7), 532-550. http://dx.doi.org/10.6007/IJARBSS/v7-i7/3120

Nemes Nagy, J. (1998). A tér a társadalomkutatásban. Budapest: Hilscher Rezső Szociálpolitikai Egyesület. http://geogr.elte.hu/REF/REF_Kiadvanyok/Ter_a_tarskutban/A_Ter_a_tarsadalomkutatasban_NNJ.htm

Nemes Nagy, J. (2016). Mezoterek a társadalomban és a gazdaságban. In Lengyel, I. \& Nagy, B. (Eds.), Térségek versenyképessége, intelligens szakosodása és újraiparosodása (pp. 105-124). Szeged: JATEPress. http://eco.u-szeged.hu/download.php?docID=59325

Nisco, A., Riviezzo, A., \& Napolitano, M. R. (2015). An Importance - Performance analysis of tourist satisfaction at destination level: evidence from Campania (Italy). European Journal of Tourism Research, Varna University of Management, 10, 64-75. https:/ejtr. vumk.eu/index.php/about/article/view/179

Nigro, H. O., \& Císaro, S. E. G. (2016). The citizen satisfaction index: Adapting the model in Argentine cities. Cities, 56(July), 85-90. https://doi.org/10.1016/j.cities.2016.03.010

Oh, H. (2001). Revisiting importance-performance analysis. Tourism Management, 22(6), 617-627. https://doi.org/10.1016/S0261-5177(01)00036-X 
Oláh, M. (2013). Balaton Kiemelt Térség Fejlesztési Programja Helyzetértékelés I. Kötet. Balatonfüred - Siófok: Balaton Fejlesztési Tanács. https://balatonregion. hu/wp-content/plugins/download-attachments/includes/download.php?id=1334

Pasaribu, P., Waryono, W., \& Saputra, R. (2016). Measurement of Visitor's Satisfaction through Importance Performance Analysis (IPA) Method About Servicescape. In International Conference on Tourism, Gastronomy, and Tourist Destination (ICTGTD 2016). Atlantis Press. https://doi.org/10.2991/ictgtd-16.2017.47

Piskóti, I., Dankó, L., Molnár, L., Nagy, S., \& Szántó, Á. (2013). A társadalmi marketing paradigmái-elméleti-módszertani alapozó kutatás. OTKA Kutatási Jelentések. http://www.marketing-turizmus. hu/otka/11.pdf

Piskóti, I., Nagy, S., Molnár, L., \& Marien, A. (2012). Identification between individuals and places of residence. In Fam K., Józsa L. \& Yang L. (eds.), Conference Proceedings of Retracing the Silkroad: MAG Scholar Global Business Marketing and Turism Conference (pp. 1-10). http://www.marketing-turizmus.hu/otka/12.pdf

Ramirez-Hurtado, J. M. (2017). The use of importance-performance analysis to measure the satisfaction of travel agency franchisees. Revista de Administração de Empresas, 57(1), 51-64. http://dx.doi.org/10.1590/S0034-759020170105

Riviezzo, A., Nisco, A., \& Napolitano, M. R. (2009). Importance-performance analysis as a tool in evaluating town centre management effectiveness. International Journal of Retail \& Distribution Management, 37(9), 748-764. https://doi.org/10.1108/09590550910975808

Shieh, I. J., \& Wu, H. (2009). Applying importance-performance analysis to compare the changes of a convenient store. Quality \& Quantity, 43(1), 391-400. https://doi.org/10.1007/s11135-007-9111-5
Silva, F., \& Fernandes, P. (2010). Using importance-performance analysis in evaluating institutions of higher education: A case study. In 2010 International Conference on Education and Management Technology (pp. 121-123). https://doi.org/10.1109/icemt.2010.5657689

Silva, F. H., \& Fernandes, P. O. (2011). Importance-performance analysis as a tool in evaluating higher education service quality: the empirical results of ESTiG (IPB). In Soliman, K. S. (ed.), The 17th International Business Information Management Association Conference (pp. 306-315). Milánó: University of Pavia. http:// hdl.handle.net/10198/7120

Szabó, M., Tóth-Kaszás, N., Jakobi, Á. \& Banász, Zs. (2019). Szakértői jelentés a KRAFT-index Nagykanizsa-Murafölde felméréséröl. Kőszeg: Felsőbbfokú Tanulmányok Intézete (FTI), Institute of Advanced Studies (iASK), KRAFT Központ.

Szirmai, V., \& Váradi, Zs. (2009). A várostérségi társadalmak versenyképesség-felfogása. In Szirmai V. (ed.), $A$ várostérségi versenyképesség társadalmi tényezői (pp. 185-190). Budapest-Pécs: Dialóg Campus.

Tóth-Kaszás, N. (2018). A települési kötődés és a $Z$ generáció - egy magyarországi középváros példája. Deturope, 10(2), 54-74. http:/www.deturope.eu/img/ upload/content_64550946.pdf

Wade, D. J., \& Eagles, P. F. (2003). The use of importance-performance analysis and market segmentation for tourism management in parks and protected areas: An application to Tanzania's national parks. Journal of Ecotourism, 2(3), 196-212. https://doi.org/10.1080/14724040308668144

Zenker, S., Petersen, S., \& Aholt, A. (2013). The Citizen Satisfaction Index (CSI): Evidence for a four basic factor model in a German sample. Cities, 31(April), 156-164.

https://doi.org/10.1016/j.cities.2012.02.006 